\title{
Crime and justice
}

- In 2007/08 the crime most commonly recorded by police in England and Wales ( 36 per cent) and Scotland (33 per cent) was theft and handling stolen goods. In Northern Ireland it was criminal damage (28 per cent). (Table 9.1)

- Between 2006/07 and 2007/08 there was a 10 per cent decrease in the incidence of crime measured by the British Crime Survey (BCS) in England and Wales, from 11.3 million to 10.1 million crimes. (Figure 9.2)

- Violent crime, which comprises assault with or without injury, wounding and robbery, accounted for one-fifth ( 2.2 million incidents) of all BCS crime in England and Wales in 2007/08. (Table 9.3)

- In 2006, 26 per cent of ten to 25-year-olds in England and Wales were victims of personal crime in the last 12 months, including robbery, personal theft and assault (either with or without injury). (Table 9.4)

- In $2007 / 08$ there were 17,300 crimes reported to the police in England and Wales in which a firearm was used, a 6 per cent decrease from 2006/07. (Figure 9.7)

- Of offenders aged 18 and over leaving prison or starting a community sentence in England and Wales in the first quarter of 2006, 39 per cent reoffended within one year, the lowest reoffending rate since the series began.

(Page 136) 
Crime can affect anyone, regardless of whether or not they have been a victim. In addition to suffering or loss resulting directly from crime, people may be affected by their perceptions of changing crime levels and their fear of crime may affect the way they live their daily lives. Dealing with crime and associated problems is an ever-present concern for society and the Government. There are two main sources of crime statistics: police-recorded crime and household population surveys of crime (see Measures of crime text box).

\section{Crime levels}

This chapter discusses both the incidence and prevalence of crime (see Appendix, Part 9: Prevalence rates and incidence rates). The incidence of crime, defined as the number of crimes that have taken place, is analysed in this section. The

\section{Measures of crime}

There are two main measures of the extent of crime in the UK: surveys of the public, and crime recorded by the police. The British Crime Survey (BCS) interviews adults aged 16 and over who are living in private households in England and Wales. The Scottish Crime and Victimisation Survey (SCVS) and the Northern Ireland Crime Survey (NICS) interview adults aged 16 and over in Scotland and Northern Ireland respectively. In some ways the BCS, the SCVS and the NICS give a better measure of many types of crime than policerecorded crime statistics. These surveys show the large number of offences that are not reported to the police and also give a more reliable picture of trends, as they are not affected by changes in levels of reporting to the police or by variations in police recording practice (see Appendix, Part 9: Types of offence in England and Wales, in Scotland, and in Northern Ireland).

Recorded crime data cover offences reported to and recorded by the police. The National Crime Recording Standard (NCRS), introduced in England and Wales in 2002 and the Scottish Crime Recording Standard (SCRS), introduced in 2004, were implemented with the aim of taking a more victim-centred approach and providing consistency between police forces (see Appendix, Part 9: National Crime Recording Standard).

Police-recorded crime and survey-measured crime have different coverage. Unlike crime data recorded by the police, surveys are generally restricted to crimes against adults living in private households and their property and do not include some types of crime (for example, fraud, murder and victimless crimes such as drug use, where there is not a direct victim).

See also Appendix, Part 9: Availability and comparability of data from constituent countries. prevalence of crime, or the proportion of people who were victims, is covered in the Offences and victims section later in the chapter.

Following the introduction of the National Crime Recording Standard (NCRS) in England and Wales in 2002 (see Appendix, Part 9: National Crime Recording Standard) there was an overall increase in the number of crimes recorded by the police that year, with less serious crimes, including criminal damage, minor theft and assault without injury, increasing the most. The introduction of the Scottish Crime Recording Standard (SCRS) in April 2004 resulted in similar increases in the number of less serious crimes recorded by the police in Scotland.

In 2007/08 around 5.5 million crimes were recorded by the police across the UK (Table 9.1). Nearly three-quarters (72 per cent) of recorded crimes in England and Wales were property crimes; these include theft and handling stolen goods, burglary, criminal damage, and fraud and forgery. Violence against the person accounted for around one-fifth (19 per cent) of all recorded crime in England and Wales, the same proportion as in 2006/07.

\section{Table 9.1}

\section{Crimes recorded by the police: by type of offence, ${ }^{1}$ 2007/08}

United Kingdom

Percentages

\begin{tabular}{lrrr}
\hline & $\begin{array}{r}\text { England } \\
\text { \&Wales }\end{array}$ & Scotland & $\begin{array}{r}\text { Northern } \\
\text { Ireland }\end{array}$ \\
\hline Theft and handling stolen goods & 36 & 33 & 23 \\
$\quad$ Theft from vehicles & 9 & 4 & 3 \\
$\quad$ Theft of vehicles & 3 & 3 & 3 \\
Criminal damage & 21 & 31 & 28 \\
Violence against the person ${ }^{2}$ & 19 & 3 & 27 \\
Burglary & 12 & 7 & 11 \\
Drugs offences & 5 & 11 & 3 \\
Fraud and forgery & 3 & 2 & 3 \\
Robbery & 2 & 1 & 1 \\
Sexual offences & 1 & 1 & 2 \\
Other offences & & 12 & 3 \\
All notifiable offences & & & 108 \\
$\quad(=100 \%$ ) (thousands) & 4,951 & 386 & \\
\hline
\end{tabular}

1 See Appendix, Part 9: Types of offence in England and Wales, in Scotland, and in Northern Ireland, and Availability and comparability of data from constituent countries.

2 Data for Scotland are serious assaults only. Those for England and Wales and Northern Ireland are all assaults including those that cause no physical injury.

3 Northern Ireland includes 'offences against the state'. Scotland excludes 'offending while on bail'.

Source: Home Office; Scottish Government; Police Service of Northern Ireland 
The definition of crime in Northern Ireland is broadly comparable with that used in England and Wales. In 2007/08 the police in Northern Ireland recorded 108,000 crimes, nearly two-thirds (65 per cent) of which were property crimes More than one-quarter (27 per cent) of recorded crime in Northern Ireland involved violence against the person, again showing little change from 2006/07.

In Scotland the term 'crime' is reserved for the more serious offences, broadly equivalent to 'indictable' and 'triable-eitherway' offences in England and Wales, while less serious crimes are called 'offences' (see Appendix, Part 9: Availability and comparability of data from constituent countries). In 2007/08, 386,000 crimes were recorded by the police in Scotland. The most common recorded crime in Scotland was theft and handling stolen goods (33 per cent), followed by criminal damage (31 per cent), unchanged from 2006/07.

The number of crimes recorded by the police tends to be lower than that reported by household surveys, largely because survey respondents identify a large number of offences that have not been reported to the police. Based on the 2007/08 British Crime Survey (BCS), 42 per cent of incidents of BCS comparable crime in England and Wales, that is crimes where BCS data can be directly compared with police statistics (see Appendix, Part 9: Comparable crimes), were reported to the police, or became known to the police by some other means. Victims gave a variety of reasons for not reporting crime to the police, with the most common being that they felt the crime was too trivial, there was no loss or that in their view the police would not, or could not, do anything about it.

The incidence of crime estimated by the BCS in England and Wales rose steadily throughout the 1980s and early 1990s and peaked in 1995, at 19.4 million offences. There was then a steady decline and the level remained relatively stable between 2004/05 and 2006/07. However, between 2006/07 and 2007/08 there was a 10 per cent decrease in the incidence of BCS crime, from 11.3 million to 10.1 million crimes and the level of crime in 2007/08 was almost one-half the level in the peak year of 1995 (Figure 9.2). The Northern Ireland Crime Survey (NICS) estimated that 199,000 crimes were committed against adults living in private households in the 12 months prior to interview in 2007/08. This was an increase from 195,000 crimes identified in 2006/07, but still much lower than the 295,000 identified in the 2003/04 NICS. Because there was no Scottish Crime and Victimisation Survey (SCVS) in 2007, the most recent available data for Scotland are for 2005/06. The survey estimated that around 1.1 million crimes were committed against adults in private households in the 12 months prior to interview in 2005/06, an increase from

\section{Figure 9.2}

\author{
British Crime Survey offences ${ }^{1}$ \\ England \& Wales \\ Millions
}

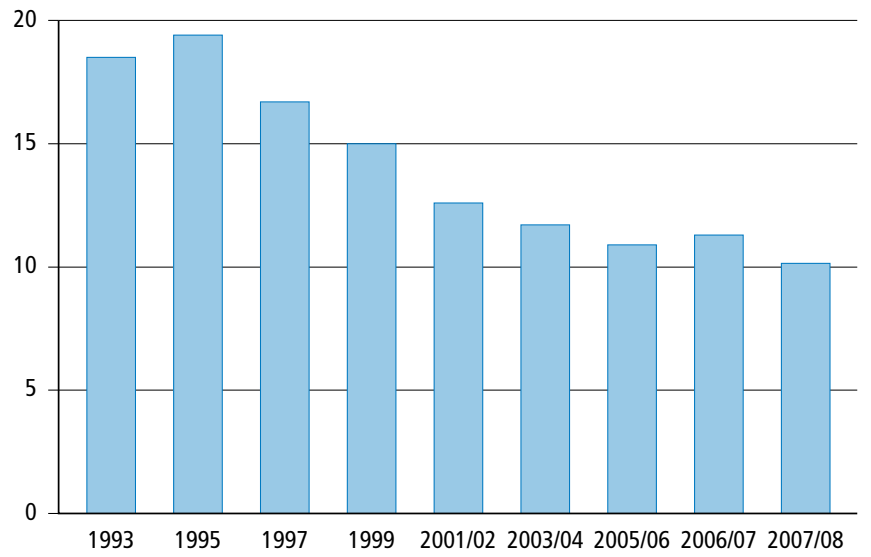

1 Until 2000, respondents were asked to recall their experience of crime in the previous calendar year. From 2001/02 onwards the British Crime Survey became a continuous survey and the recall period was changed to the 12 months prior to interview.

Source: British Crime Survey, Home Office

900,000 in $2003 / 04$. The incidence of SCVS crime in $2005 / 06$ was at the same level it was in 1992.

Of the 10.1 million crimes reported by the BCS in England and Wales in 2007/08, almost two-thirds (6.4 million) were household crimes and more than one-third (3.7 million) were personal crimes (Table 9.3 overleaf). There was an overall reduction in the incidence of both types of crime reported in 2007/08. The most common crime reported, accounting for more than one-quarter of all BCS crime, was vandalism, with an estimated 2.7 million incidents experienced in the 12 months prior to interview. This was the most commonly experienced household crime each year since 2001/02, but during the 1990 s vehicle theft was the most common, ranging from 3.5 million to 4.4 million crimes. Violent crime, which comprises assault with or without injury, wounding and robbery, accounted for one-fifth (2.2 million incidents) of all BCS crime reported in 2007/08.

\section{Offences and victims}

The likelihood of being a victim of crime varies according to where you live. The highest levels of household crime in England and Wales according to the 2007/08 British Crime Survey (BCS), including theft of, or from, vehicles, bicycle theft, household theft, burglary, and vandalism, were experienced by those living in Yorkshire and the Humber where one-fifth (20 per cent) of households reported being a victim once or more in the 12 months prior to interview. The North East 
Table 9.3

\section{Incidents of crime: by type of offence ${ }^{1}$}

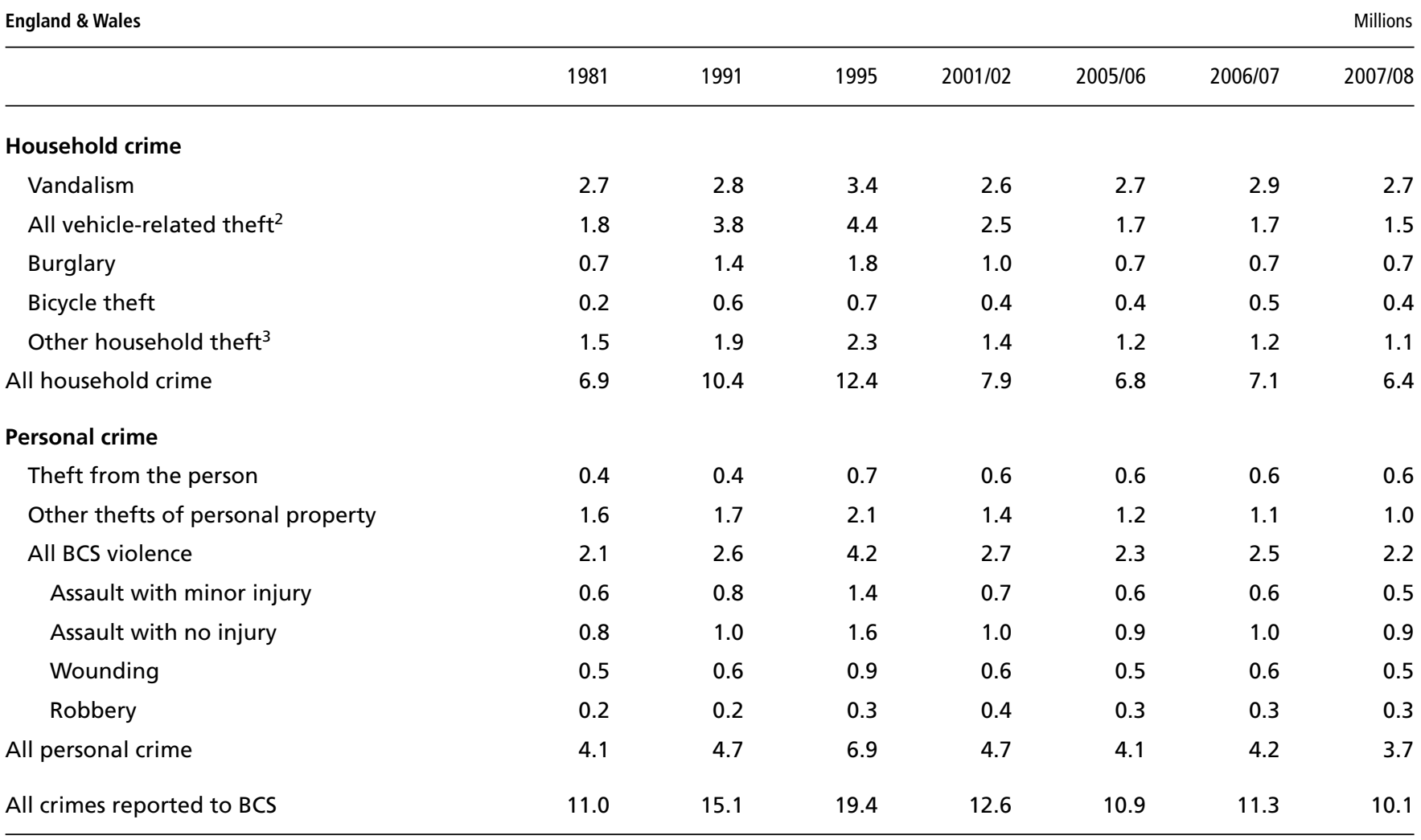

1 Until 2000 respondents were asked to recall their experience of crime in the previous calendar year. From 2001/02 onwards the British Crime Survey (BCS) became a continuous survey and the recall period was changed to the 12 months prior to interview.

2 Includes theft of, or from, a vehicle, as well as attempts.

3 Includes thefts and attempted thefts from domestic garages, outhouses and sheds, not directly linked to the dwelling, as well as thefts from both inside and outside a dwelling.

Source: British Crime Survey, Home Office

(19 per cent) and the North West (18 per cent) had the next highest incidence of household crime. The lowest incidence was reported by those living in the South West (14 per cent). There are also differences in the characteristics of those households more at risk and this varies by the type of crime. For example, households with no security measures were more than ten times as likely than average to be victims of burglary according to the 2007/08 BCS, and households headed by someone aged 16 to 24 were three times more likely than average to be burgled.

The highest rate of personal crime, including assault, sexual offences, robbery, theft from the person and other personal theft, was experienced by those living in London, with 8 per cent having been victims in the 12 months prior to interview. The areas with the lowest risk of personal crime were Wales and the South West, at 5 per cent each. Risk of personal crime also varied according to the characteristics of the victim. Men and women aged 16 to 24 were more likely to have experienced a violent offence than those in any other age group. The risk for young men was more than double that for young women (13 per cent compared with 6 per cent) and although the difference declined with age, men of all ages were more likely than women to have experienced a violent offence. The risk of being a victim of violence had decreased to less than 1 per cent by the age of 55 for women and age 65 for men.

The incidence of personal crime continues to be high among young people aged under 26. The 2006 Offending, Crime and Justice Survey (OCJS) reported that 12 per cent of ten to 25-year-olds had experienced at least one incident of personal theft in England and Wales in the 12 months prior to interview (Table 9.4). More than one-quarter (26 per cent) were victims of some kind of personal crime over the same period, including robbery, personal theft and assault (either with or without injury). Young males were more likely than young females to be victims of a personal crime within the last 12 months (31 per cent compared with 21 per cent). The difference was most pronounced among ten to 15-year-olds; nearly two-fifths (38 per cent) of boys of this age group were victims compared with around one-fifth (22 per cent) of girls. 
Table 9.4

Young people who were victims of personal crime: ${ }^{1}$ by age and sex, 2006

\begin{tabular}{|c|c|c|c|c|c|c|c|}
\hline & \multicolumn{3}{|c|}{ Males } & \multicolumn{3}{|c|}{ Females } & \multirow{2}{*}{$\begin{array}{r}\text { All aged } \\
10-25\end{array}$} \\
\hline & $10-15$ & $16-25$ & All & $10-15$ & $16-25$ & All & \\
\hline Any personal thefts & 17 & 11 & 13 & 8 & 11 & 10 & 12 \\
\hline Robbery & 2 & 3 & 2 & 1 & 1 & 1 & 2 \\
\hline Theft from the person & 7 & 5 & 5 & 3 & 5 & 4 & 5 \\
\hline Other personal thefts & 11 & 6 & 8 & 5 & 7 & 6 & 7 \\
\hline Any assault & 28 & 18 & 22 & 15 & 11 & 12 & 17 \\
\hline Assault (no injury) & 21 & 10 & 14 & 11 & 7 & 8 & 11 \\
\hline Assault (with injury) & 14 & 11 & 12 & 7 & 5 & 6 & 9 \\
\hline Any personal crime & 38 & 27 & 31 & 22 & 20 & 21 & 26 \\
\hline
\end{tabular}

1 In the 12 months prior to interview.

Source: Offending, Crime and Justice Survey, Home Office

According to the 2006 OCJS, the most common type of personal crime among ten to 25-year-olds was assault, at 17 per cent, with 11 per cent of young people being victims of assault without injury and 9 per cent victims of assault with injury. Males aged ten to 25 had the highest victimisation rates for these crimes, at 14 per cent and 12 per cent respectively, around double the rates for females ( 8 per cent and 6 per cent respectively). While the definition of personal victimisation in the survey is broadly consistent with the BCS, the questions are adjusted to make them suitable for the younger respondents, and are asked in a different context, so it is not possible to draw direct comparisons between the OCJS and BCS measures of victimisation.

The 2006/07 BCS showed that in England and Wales, 2 per cent of individual mobile phone owners had their mobile stolen in the last 12 months, the same proportion as in 2005/06. Mobile phone theft varied by age of the victim with children aged 12 to 15 and young adults aged 16 to 24 being the most likely to experience mobile phone theft in the last 12 months, around 5 per cent of each group of owners (Figure 9.5). Around 2 per cent of adults aged between 25 and 44 had their mobile stolen in the last 12 months. The 2006/07 BCS asked adults aged 16 and over who had personally experienced a theft (therefore excluding other household members and children) about the circumstances of the theft Nearly one-quarter (24 per cent) reported that the theft had taken place while the victim was on public transport or in another public place, such as a shop or hospital. A further 22 per cent had their phone stolen from a bar, pub or club.
The 2007/08 BCS asked victims of violent incidents (including wounding, assault with minor injury, assault with no injury and robbery) whether they believed the offender to have been under the influence of alcohol or drugs (except in incidents where the victim perceived the offender to be under school-leaving age or could not describe the offender). More than two-fifths (45 per cent) of victims of violent offences believed the offender to be under the influence of alcohol.

\section{Figure 9.5}

Mobile phone owners experiencing theft: ${ }^{1}$ by age, 2006/07

\section{England \& Wales}

Percentages

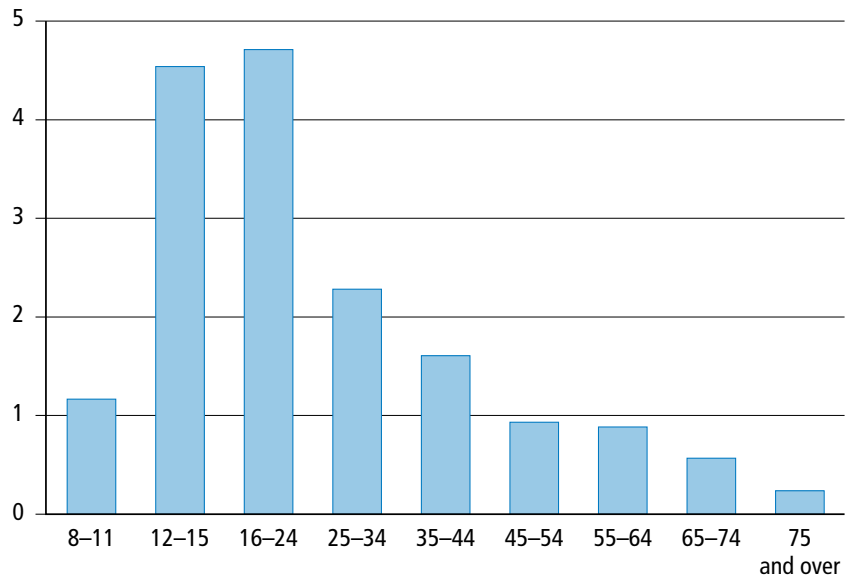

1 Based on the number of people who experienced theft of at least one mobile phone in the last 12 months. Does not reflect the number of phones stolen.

Source: British Crime Survey, Home Office 
Violence committed by a stranger was the most common type of incident in which victims believed the offender was under the influence of alcohol (58 per cent) followed by violent incidents committed by an acquaintance ( 48 per cent) (Table 9.6). The most common type of offence was assault with minor injury, with around three-fifths (61 per cent) of victims seeing alcohol as a contributing factor. It is harder for victims to identify whether the perpetrator of their violent incident was under the influence of drugs but this too was most commonly identified in incidents of assault with minor injury (24 per cent).

The introduction of The Licensing Act 2003 in November 2005 abolished set licensing hours in England and Wales with the aim of passing responsibility for licensing from the magistrates' courts to local authorities. Although this led to some concerns about introducing a '24-hour drinking culture', the aim was to reduce the problems of heavy drinking and disorder associated with a standard closing time and, over the longer term, encourage a more relaxed drinking culture. The Home Office evaluation of the impact of the Act on crime and disorder found that there was little evidence to support concerns about increased violence. Comparing the 12 months before and after implementation, a survey of 30 police forces showed falls in the number of recorded incidents involving violence, criminal

\section{Table 9.6}

\section{Proportion of violent incidents where the offender was perceived to be under the influence of alcohol or drugs, ${ }^{1,2} 2007 / 08$}

England \& Wales

Percentages

\begin{tabular}{llll}
\multicolumn{2}{c}{ Alcohol } & & \multicolumn{2}{c}{ Drugs } \\
${ } }$ & Yes No
\end{tabular}

\section{Type of violence}

$\begin{array}{lllll}\text { Domestic } & 37 & 61 & 12 & 82 \\ \text { Mugging } & 17 & 63 & 13 & 58 \\ \text { Stranger } & 58 & 28 & 14 & 47 \\ \text { Acquaintance } & 48 & 46 & 28 & 51 \\ \text { ype of offence } & & & & \\ \text { Wounding } & 48 & 42 & 15 & 60 \\ \text { Robbery } & 19 & 63 & 14 & 58 \\ \text { Assault with minor injury } & 61 & 32 & 24 & 49 \\ \text { Assault with no injury } & 44 & 47 & 20 & 56 \\ \text { All violence } & 45 & 45 & 19 & 56\end{array}$

1 Percentages do not sum to 100 per cent as victims could answer 'don't know'.

2 Question not asked if offenders were perceived to be of school age.

Source: British Crime Survey, Home Office damage and harassment ( 1 per cent) and in serious violent crimes (5 per cent). However, the timing of these incidents changed with a small rise in the number of incidents between $6 \mathrm{pm}$ and 6 am and a 25 per cent increase in the number of offences committed between 3 am and 6 am. In addition, the BCS Night Time Economy Module shows that there was no significant change following the introduction of the Act in the proportion of people who said they felt unsafe in town centres at night, or who had witnessed drunken anti-social behaviour in town centres.

The 2007/08 BCS estimated that there were nearly 2.2 million violent incidents against adults in England and Wales, a decrease of 12 per cent since 2006/07 (see Table 9.3). Weapons were used in nearly one-quarter (24 per cent) of all violent incidents, the same proportion as in $2006 / 07$. This proportion has remained stable over the last decade. Weapons were most commonly used in offences of robbery, wounding, and assault with no injury, with around one-quarter of these incidents each involving the use of some kind of weapon (23 per cent, 26 per cent and 27 per cent respectively).

Hitting implements (including sticks and clubs) and knives were the most common weapons used in violent incidents reported in the 2007/08 BCS (used in 7 per cent and 6 per cent of incidents respectively). A knife was used in 15 per cent of robberies and 8 per cent of woundings. Nearly one-half (49 per cent) of victims of violent incidents in 2007/08 sustained a physical injury.

In 2007/08 around one-fifth (19 per cent) of police-recorded serious offences in England and Wales, including attempted murder, wounding with intent to do grievous bodily harm $(\mathrm{GBH})$, wounding or inflicting $\mathrm{GBH}$ (without intent) and robbery (of business or personal property) involved a knife or sharp instrument.

In 2007/08 there were 17,343 crimes reported to the police in England and Wales in which a firearm was used, a 6 per cent decrease from 18,481 offences in $2006 / 07$. The number of offences involving a firearm increased every year from 1998/99 (13,874 offences) to peak in 2002/03 and 2003/04 at around 24,000 offences. The number of firearm offences then began to decline and the decrease in 2007/08 was the fourth consecutive fall since 2003/04. Air weapons were reported to have been used in 7,478 offences in 2007/08, a decrease from 8,836 in 2006/07 (Figure 9.7), and accounted for more than two-fifths (43 per cent) of all firearm offences. However, offences involving a firearm excluding air weapons increased by 2 per cent between 2006/07 and 2007/08; from 9,645 to 9,865 offences. Handguns were the most common type of 


\section{Figure 9.7}

\section{Crimes ${ }^{1}$ reported to the police in which a firearm had been used}

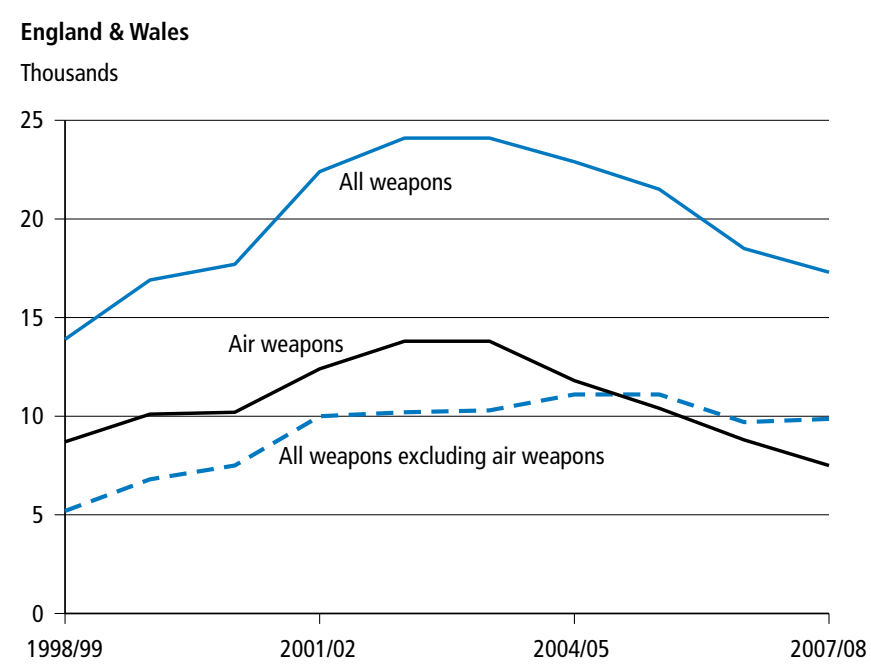

1 Changes in counting offences were made in April 1998 and the National Crime Recording Standard was implemented in April 2002. See Appendix, Part 9: National Crime Recording Standard.

Source: Home Office

non-air weapon used, and were involved in more than two-fifths (42 per cent) of all non-air weapon firearm offences in $2007 / 08$.

Firearms are defined as having been involved in an incident if they have been discharged (fired), used as a blunt instrument against a person, or used as a threat. In 2007/08 more than nine in ten (92 per cent) air weapons involved in incidents were fired compared with around three-quarters (73 per cent) of imitation firearms, around one-half (53 per cent) of rifles, unidentified and 'other' weapons, and more than one-third (37 per cent) of shotguns. Handguns were the least likely to be fired with only 10 per cent of handguns involved in incidents being fired. However, handguns that were fired were the most likely firearm to result in a fatal or serious injury (36 per cent) compared with 1 per cent as a result of discharged air weapons.

In Scotland in 2007/08 there were 1,125 firearm offences recorded by the police. More than one-half (576) involved air weapons (including air guns, air pistols, air rifles and BB guns). The proportion of crimes involving a firearm has decreased by 11 per cent since 2006/07 and those involving air weapons has decreased by 17 per cent.

In Northern Ireland there were 544 crimes reported to the police in 2007/08 in which a firearm was used, a 9 per cent decrease compared with 2006/07. Between 2005/06 and 2006/07 there was a 35 per cent decrease. While crimes involving firearms excluding air weapons decreased by
12 per cent, those involving air weapons decreased by 2 per cent between 2006/07 and 2007/08.

The risk of being a victim of homicide (which includes the offences of murder, manslaughter and infanticide) continues to be low in England and Wales. In 2007/08 there were 763 offences recorded, a 3 per cent increase on the number recorded in 2006/07 and a rate of 14.1 per million population. Homicide figures are based on the year they are recorded by the police and not the year they occur so trend data should be treated with caution (see Appendix, Part 9: Homicides). However, over the last ten years the homicide rate has remained relatively stable, between 13 and 15 per million population, apart from an increase in 2002/03 to 18 per million population. This increase resulted from 172 homicides attributed to Harold Shipman which, although took place over a number of years, were recorded in 2002/03 following Dame Janet Smith's inquiry.

Males are more at risk of homicide than females; around three-quarters (73 per cent) of all homicide victims were male in 2007/08. The risk was highest for men aged 16 to 20 , at 45 per million population (Figure 9.8). This is a change from 2006/07 where men aged 21 to 29 had the highest risk of homicide, at 42 per million population compared with 29 per million for those aged 16 to 20. For females the highest risk of homicide in 2007/08 was for infants under one year old, at 30 per million population. The homicide rate for males was higher than that for females at all ages apart from those aged 70 and over when the rate was slightly lower.

\section{Figure 9.8}

\section{Offences recorded as homicide: ${ }^{1}$ by sex and age of victim, 2007/08}

England \& Wales

Rates per million population

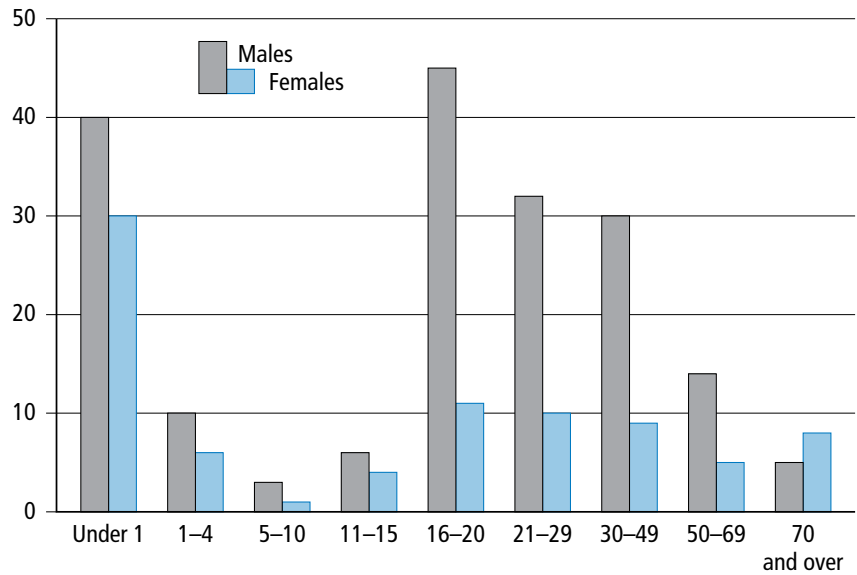

1 Offences currently recorded as homicide as at 4 November 2008. Figures are subject to revision as cases are dealt with by the police or courts, or as further information comes to light. See Appendix, Part 9: Homicides.

Source: Home Office 
In 2007/08 more than one-third (35 per cent) of all homicide victims were apparently killed by sharp instruments. This was the most common method of killing for both male and female victims with 212 and 58 offences respectively. For males the second most common method was 'hitting and kicking, etc.' (140 offences) but for females it was strangulation, including asphyxiation (41 offences).

In Scotland there were 114 offences currently recorded as homicide in 2007/08, a rate of 22 per million population. Around four-fifths (79 per cent) of the victims were male. People aged 16 to 30 were at the highest risk, with a rate of 38 homicides per million population overall, and men were again particularly at risk, at 64 per million population in this age group. However, as in England and Wales, the number of homicides in Scotland was very small and these offences accounted for 0.1 per cent of all violent crime (which includes homicide, attempted murder, sexual assault, abduction, serious assault, minor assault and robbery).

In Northern Ireland there were 24 offences currently recorded as homicide in 2006/07, a rate of 14 per million population, the same as for England and Wales. Most of the victims (19) were men and the homicide rate was highest among men aged 30 to 49 years old with 11 of the male victims in this age group.

\section{Perceptions of crime}

The 2007/08 BCS reported that despite a decrease in the incidence of crime in England and Wales, almost two-thirds (65 per cent) of people perceived there to be more crime (either 'a lot more' or 'a little more') than two years ago in the country as a whole. This perception was unchanged since 2006/07 (Table 9.9). More than one-third (35 per cent) of respondents perceived that crime had increased a lot in the country as a whole. People were more positive about their local area, with 39 per cent perceiving there was either a little or a lot more crime than two years ago. The proportion of people perceiving more crime in the country as a whole has remained fairly stable since 2003/04, but the proportion perceiving more crime in their local area has decreased from 54 per cent in 2002/03.

The Northern Ireland Crime Survey (NICS) showed that the proportions of people in Northern Ireland perceiving more crime in the country as a whole and in their local area were similar to those for England and Wales in 2007/08. However, both these proportions had decreased compared with 2006/07, from 73 per cent to 65 per cent for the whole country and from 44 per cent to 39 per cent for crime in the local area.

Respondents to these crime surveys were asked how likely they thought they were to be victims of particular crimes in the

\section{Table 9.9}

\section{Perceptions of changing crime levels ${ }^{1}$}

\begin{tabular}{lrr} 
England \& Wales & & Percentages \\
\hline & Whole country & Local area ${ }^{2}$ \\
\hline $2001 / 02$ & 65 & 51 \\
$2002 / 03$ & 72 & 54 \\
$2003 / 04$ & 65 & 48 \\
$2004 / 05$ & 61 & 42 \\
$2005 / 06$ & 63 & 42 \\
$2006 / 07$ & 65 & 41 \\
$2007 / 08$ & 65 & 39
\end{tabular}

1 British Crime Survey (BCS) respondents were asked if they thought there was more or less crime than two years ago and given the following options; 'A lot more', 'a little more', 'about the same', 'a little less' or 'a lot less'. Data are the proportion of people who answered 'a lot more' or 'a little more'.

2 Question only asked of respondents who had lived in their area for three years or more.

Source: British Crime Survey, Home Office

12 months following their interview. According to the 2007/08 BCS, 14 per cent of people in England and Wales thought they were likely (either 'very likely' or 'fairly likely') to be victims of burglary or violent crime and 23 per cent of car owners thought they were likely to be victims of vehicle crime. However, in the same year the actual incidence of these crimes reported to the BCS was much lower. Around 6 per cent of households reported being a victim of vehicle related theft or damage in the previous 12 months, 2 per cent reported being victims of burglary, and 3 per cent of adults had experienced violent crime in the last 12 months. Apart from men aged 16 to 24 , the crime both men and women thought they were most likely to experience was vehicle crime (Figure 9.10). Men aged 16 to 24 , however, perceived they were more likely to be victims of violent crime. When analysed by marital status, respondents who were separated were the most likely to think they would be a victim of vehicle crime (31 per cent) within the next 12 months, while one-fifth (20 per cent) of single people thought they were likely to be a victim of violent crime. However, people who were widowed were the least likely of all marital status groups to think that they would be a victim of vehicle crime, burglary or violent crime within the next 12 months.

In 2007/08 both men and women in Northern Ireland felt they were more likely to be victims of vehicle crime than any other crime within the next 12 months. This was true for all ages although the perception was most prevalent among men aged 55 to 64 (28 per cent) and among women aged 25 to 34 (25 per cent). One-fifth (21 per cent) of young men aged 16 to 


\section{Figure 9.10}

\section{Perceived likelihood of being a victim of crime: ${ }^{1,2}$ by sex and age, 2007/08}

\section{England \& Wales}

Percentages
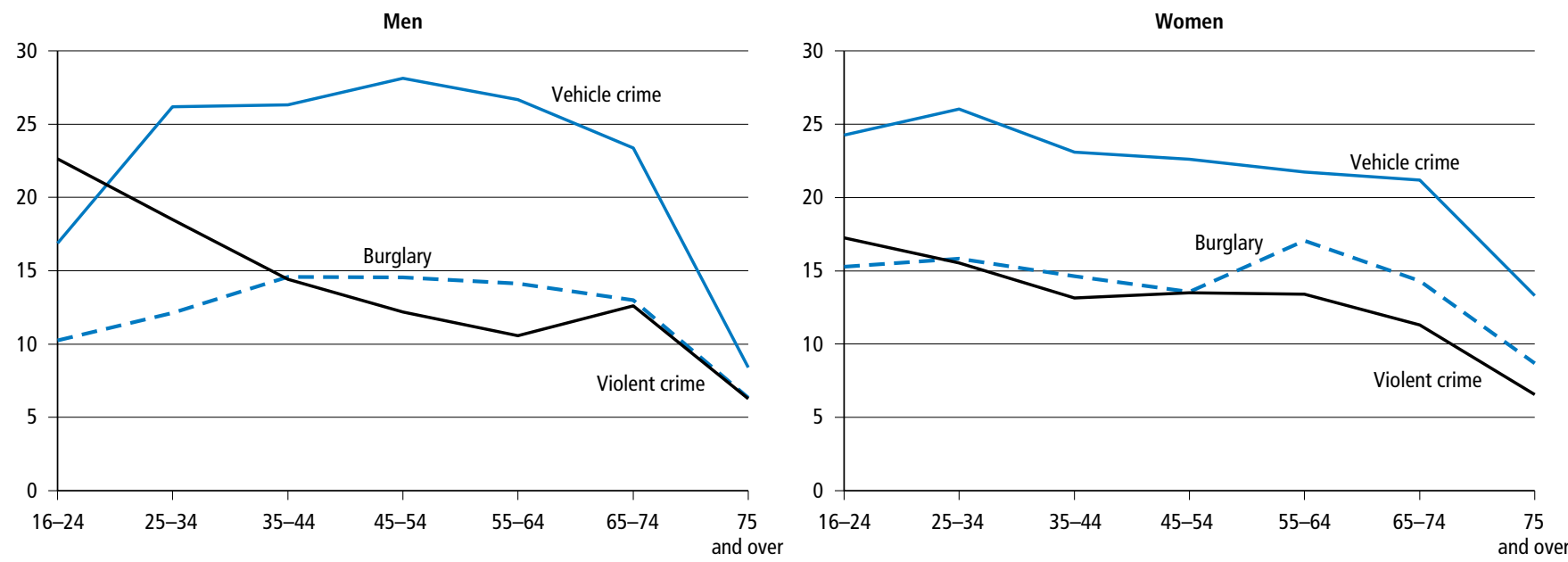

1 Those who answered they were 'fairly' or 'very likely' to be victims of each crime within the next 12 months. See Appendix, Part 9: Perceived likelihood of being a victim of crime.

2 All respondents were asked, irrespective of whether or not they had been a victim of crime in the previous 12 months.

Source: British Crime Survey, Home Office

24 felt they were likely to be victims of violent crime within the next 12 months.

\section{Offenders}

In 2007, 1.41 million offenders were sentenced for indictable and summary offences in England and Wales (see Appendix, Part 9: Types of offence in England and Wales), compared with 1.42 million in 2006. Most of the offenders were male and of these 7 per cent were aged under 18. In 2007 the peak age for men being found guilty of, or cautioned for, one or more indictable offence was 17, with 6 per cent of men of this age being found guilty or cautioned, compared with 1 per cent of women of the same age (Figure 9.11). For females the peak age for being found guilty of, or cautioned for, an indictable offence was 15 (2 per cent). As young men and women entered their 20s the proportion of offenders started to decline but this happened at a younger age for women than for men. Less than 1 per cent of women at each age over the age of 20 were found guilty of, or cautioned for, an indictable offence in 2007 but for men the proportions did not decline to less than 1 per cent until the age of 45 .

In Northern Ireland 7,600 offenders were found guilty of, or cautioned for, indictable offences in 2006. Of these, 88 per cent were male. Young men aged 19 and 20 were the most likely to be offenders with nearly 4 per cent of all men in this age group being found guilty of, or cautioned for, an indictable offence.
The proportion of women who were offenders was less than one-half of 1 per cent for all age groups.

Theft and handling stolen goods accounted for 179,000 offences in England and Wales in 2007 and was the most common indictable offence for both men and women to be

\section{Figure 9.11}

\section{Offenders ${ }^{1}$ as a proportion of the population: by sex and age, ${ }^{2} 2007$}

\section{England \& Wales}

Percentages

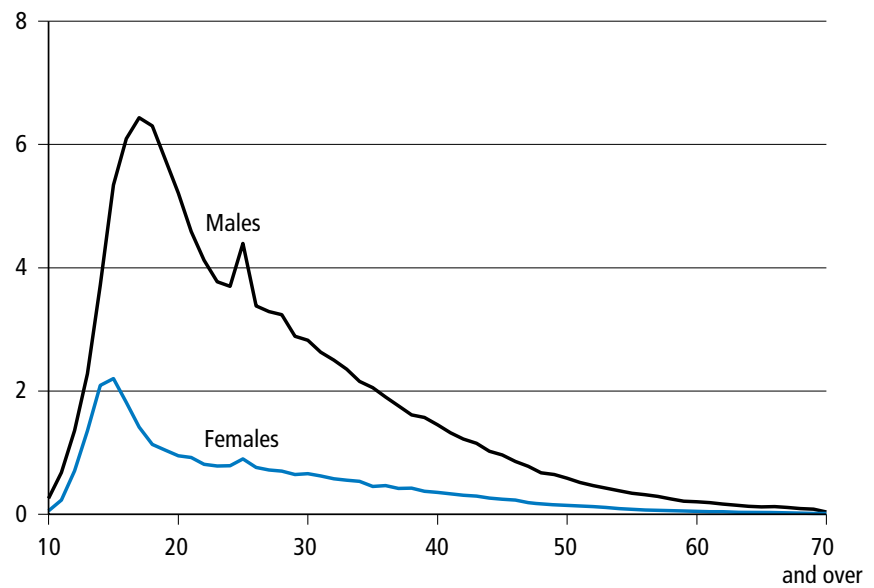

1 People found guilty of, or cautioned for, indictable offences in 2007. 2 Age 25 includes those offenders for whom age is not known.

Source: Office for Criminal Justice Reform, Ministry of Justice 
found guilty of, or cautioned for; 30 per cent of male offences and 51 per cent of female offences (Figure 9.12). The next most common offences for men were drugs offences and violence against the person, with 78,000 and 77,000 offences respectively, 19 per cent each. The proportion of men found guilty of, or cautioned for, drugs offences in 2007 was double that of women (9 per cent). For women, the next most common offences, with 17,000 each, were violence against the person and other offences (17 per cent each).

In Northern Ireland, the most common indictable offence for men to be found guilty of, or cautioned for in 2006, was violence against the person, accounting for 2,000 offences (30 per cent), followed by theft and handling stolen goods (20 per cent). For women, the most common offence to be found guilty of, or cautioned for (370 offences) was theft and handling stolen goods, accounting for two-fifths (40 per cent) of all offences.

Of the 518,000 offenders found guilty of, or cautioned for, indictable offences in England and Wales in 2007, three-fifths (60 per cent) were sentenced. The type of sentence given depends on the offence committed and other factors that may be applied on a case-by-case basis (see Appendix, Part 9: Sentences and orders). The most common sentence for indictable offences in 2007 was a community sentence

\section{Figure 9.12}

\section{Offenders found guilty of, or cautioned for, indictable offences: ${ }^{1}$ by sex and type of offence, 2007}

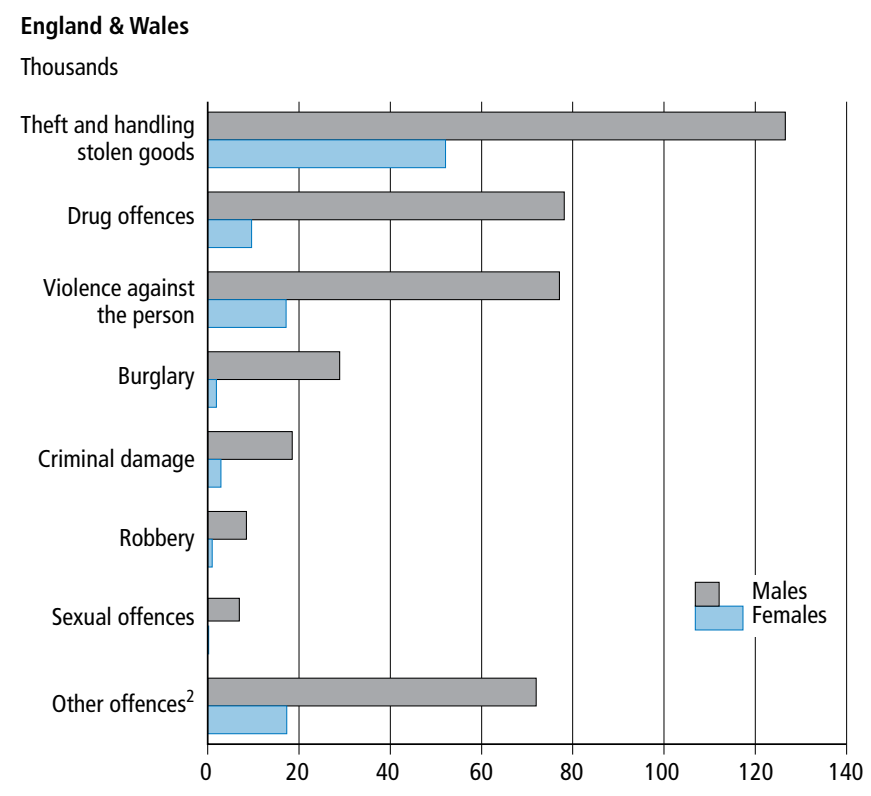

1 See Appendix, Part 9: Types of offence in England and Wales. 2 Includes fraud and forgery and indictable motoring offences. Source: Office for Criminal Justice Reform, Ministry of Justice
(34 per cent), with around one-half (46 per cent) of offenders sentenced for criminal damage and 43 per cent of those sentenced for burglary receiving this sentence (Table 9.13). Offenders committing indictable drugs offences were most commonly fined along with those convicted of 'other indictable offences' (32 per cent and 31 per cent respectively). More than one-half of those found guilty of sexual offences (56 per cent) and robbery (54 per cent) were sentenced to immediate custody. Motoring offences vary in severity and this is reflected in the variety of sentences given (see also Figure 9.17). Of those found guilty of indictable motoring offences in 2007, 29 per cent were sentenced to immediate custody, 26 per cent were given a community sentence and 23 per cent were fined.

In Northern Ireland 7,600 offenders were sentenced for indictable offences in 2007. A fine was the most common sentence for all offences apart from robbery, sexual offences and burglary, where the most common sentence was immediate custody (85 per cent, 55 per cent and 45 per cent respectively).

One aim of the criminal justice system is to try to prevent offenders from committing further crimes, so the measurement of reoffending is of considerable policy interest. One measure of adult reoffending, on which the Ministry of Justice reoffending target is based, is the frequency of reoffences committed per 100 offenders. This measure is based on the number of offences committed within one year by offenders who were released from prison or had commenced a court order under probation supervision. In 2006 there were 146 offences per 100 offenders, a decrease of 32 per cent since 2002 when the rate was 215 offences per 100 offenders.

Another way to measure adult reoffending is the actual yes/no (binary) reoffending rate. This rate counts the proportion of adult offenders released from custody or commencing a court order under probation supervision who offended at least once during a one-year follow-up period, and where the offence resulted in a conviction at court (see Appendix, Part 9: Reoffenders). This measure is therefore based purely on the number of reoffenders, however many offences they may commit during the follow-up period. Of the offenders leaving prison or starting a community sentence in the first quarter of 2006, 39 per cent reoffended within one year, the lowest reoffending rate since the series began with the 2000 cohort and a decrease from the 42 per cent who reoffended in 2005. There was an overall decline in the reoffending rate by age; 48 per cent of 18 to 20 -year-olds in 2006 reoffended within one year, more than double the rate among offenders aged 50 and over (Figure 9.14). However, offenders in this older age 
Table 9.13

Offenders sentenced for indictable offences: by type of offence ${ }^{1}$ and type of sentence, ${ }^{2} 2007$

\begin{tabular}{|c|c|c|c|c|c|c|c|}
\hline & Discharge & Fine & $\begin{array}{r}\text { Community } \\
\text { sentence }\end{array}$ & $\begin{array}{r}\text { Suspended } \\
\text { sentence } \\
\text { order }\end{array}$ & $\begin{array}{r}\text { Immediate } \\
\text { custody }\end{array}$ & Other & $\begin{array}{r}\text { All sentenced } \\
(=100 \%) \\
\text { (thousands) }\end{array}$ \\
\hline Theft and handling stolen goods & 21 & 13 & 38 & 6 & 19 & 3 & 105.5 \\
\hline Drug offences & 18 & 32 & 23 & 6 & 18 & 2 & 44.5 \\
\hline Violence against the person & 7 & 5 & 38 & 17 & 30 & 4 & 42.1 \\
\hline Burglary & 4 & 2 & 43 & 10 & 39 & 2 & 23.5 \\
\hline Fraud and forgery & 17 & 11 & 32 & 12 & 26 & 2 & 19.9 \\
\hline Criminal damage & 22 & 10 & 46 & 4 & 11 & 9 & 12.3 \\
\hline Motoring & 4 & 23 & 26 & 16 & 29 & 2 & 5.5 \\
\hline Robbery & - & - & 39 & 5 & 54 & 1 & 8.9 \\
\hline Other offences & 9 & 31 & 23 & 8 & 20 & 9 & 45.0 \\
\hline All indictable offences & 14 & 16 & 34 & 9 & 24 & 4 & 312.3 \\
\hline
\end{tabular}

1 See Appendix, Part 9: Types of offence in England and Wales.

2 See Appendix, Part 9: Sentences and orders.

Source: Ministry of Justice

group had the greatest increase in the reoffending rate, increasing from 13 per cent in 2000 to 19 per cent in 2006.

Reoffending among juveniles is measured in a similar way to adults and covers juveniles aged ten to 17 released from

\section{Figure 9.14}

\section{One-year reoffending rate: ${ }^{1}$ by age}

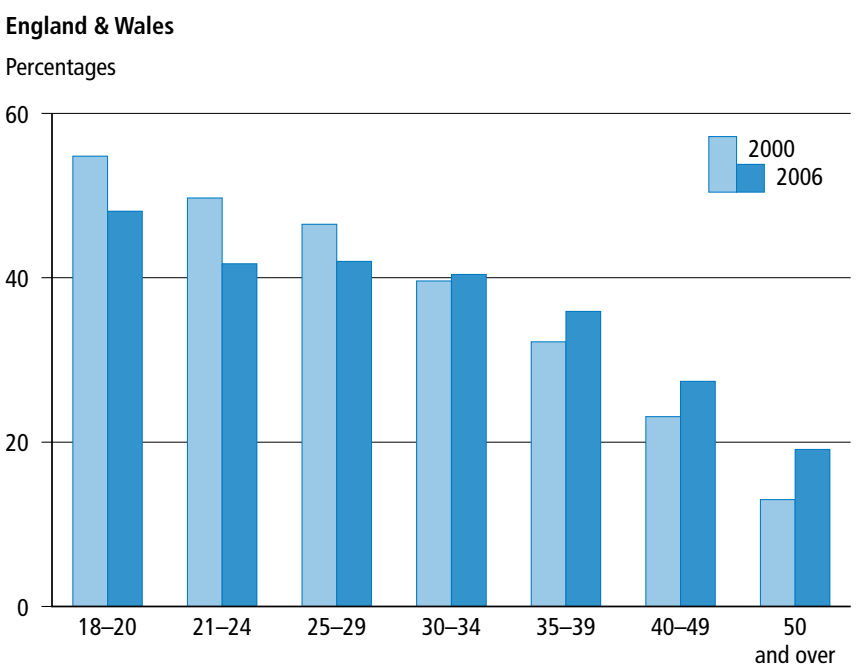

1 Percentage of all offenders reoffending at least once during the one-year follow-up period, where the reoffence resulted in conviction at court. Includes offenders aged 18 and over discharged from prison, or starting a court order supervised by the probation service, in the first quarter (January-March) of the year.

Source: Ministry of Justice custody, starting a non-custodial court disposal or those given an out-of-court disposal (see Appendix, Part 9: Reoffenders - juveniles). In 2006 the reoffending rate for juveniles was the same as that for adults (39 per cent). Although this was slightly lower than the 40 per cent reoffending rate in 2000 , the rate for juveniles has remained between 38 and 39 per cent since 2002. Juveniles committed 123 offences per 100 juvenile offenders in 2006, a 19 per cent decrease from the reoffending rate of 151 per 100 offenders in 2000.

\section{Prisons and sentencing}

Prison is the usual destination for offenders given custodial sentences or those who break the terms of their non-custodial sentence. The prison population (those held in prison or police cells, see Appendix, Part 9: Prison population for more details) in Great Britain was relatively stable in the 1980s and early 1990s but in the mid-1990s the population began to increase (Figure 9.15 overleaf). The largest increase, 10 per cent, occurred between 1996 and 1997. Apart from small decreases of less than 1 per cent in 1999 and 2000, the prison population increased every year since 1991 and in 2008 reached 91,000, almost double the population of 1980 and 4 per cent higher than in 2007.

This 4 per cent increase in the average prison population in 2008 was recorded for both sentenced and remand (which includes untried and convicted but unsentenced) prisoners. 


\section{Figure 9.15}

\section{Average prison ${ }^{1}$ population \\ Great Britain \\ Thousands}

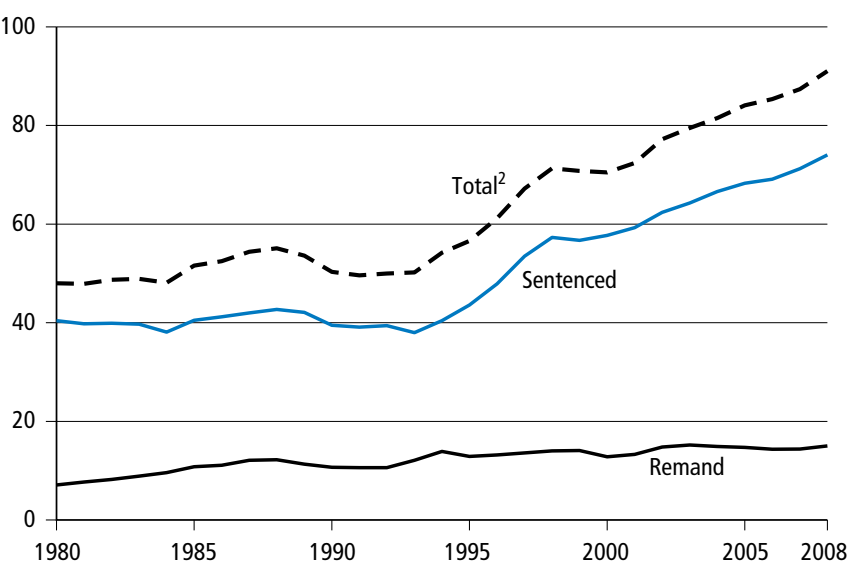

1 Includes prisoners held in police cells.

2 Includes non-criminal prisoners (for example, those held under the Immigration Act 1971).

Source: Ministry of Justice; Scottish Government

The annual average number of sentenced prisoners in Great Britain increased by 83 per cent between 1980 and 2008, from around 40,000 to 74,000 , while the number of remand prisoners more than doubled, from 7,000 to 15,000 .

Northern Ireland's prison population fell during the 1980s and 1990 s to a low of 910 in 2001 . One reason for the decrease in the late 1990s was the implementation of the Northern Ireland (Sentences) Act 1998, arising from the Belfast Agreement (Good Friday Agreement), which resulted in the release of a number of prisoners between 1998 and 2000. However, the prison population in Northern Ireland has increased progressively since that time and the population in 2007, of

In 2007 the prison population rate in England and Wales was 149 prisoners per 100,000 population. This was 21 per cent higher than the EU-27 average rate of 123 per 100,000 population, and the seventh highest in the EU-27 (Figure. 9.16). The prison population rate in Scotland was 142 per 100,000 population (15 per cent higher than the EU average) but the population in Northern Ireland, at 83 per 100,000 population, was 32 per cent lower and the seventh lowest in the EU-27. With the exception of Luxembourg, England and Wales had the highest prison population rate of the original EU-15 member states (see Appendix, Part 4: Accession to the European Union (EU)). The highest rate of the EU-27 was in Estonia, at 322 per 100,000 population and the lowest was Denmark, at 62 per 100,000 population. However, comparing prison populations across the EU is difficult because the

\section{Figure 9.16}

\section{Prison population: ${ }^{1}$ EU comparison, ${ }^{2} 2007$}

Rates per 100,000 population

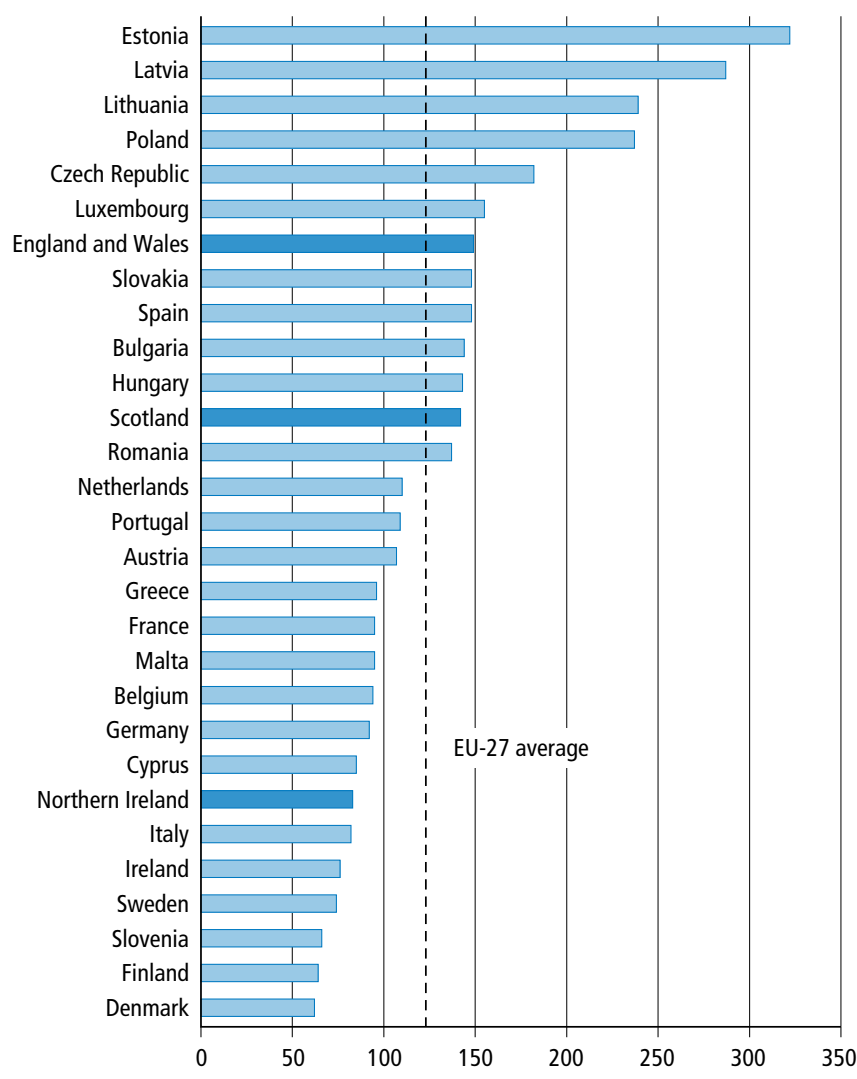

1 As at 1 September. Number of prisoners, including pre-trial detainees/remand prisoners.

2 Data for England and Wales, Scotland and Northern Ireland are presented separately because of the different criminal justice systems in these countries.

Source: Ministry of Justice

number of prisoners in custody at any one time depends on the individual penal systems in operation in each country.

Prison is just one way of dealing with offenders and in recent years there has been an increase in the use of non-criminal proceedings, such as the use of fixed penalties (fines) for a number of different crimes, including motoring offences. Overall in 2006 there were a total of 12.7 million motoring offences in England and Wales, equivalent to a rate of 422 motoring offences per 1,000 licensed vehicles. The total number of offences dealt with increased from 9.5 million in 1996 to 13.7 million in 2004 although the number then decreased in each of the following two years to 2006. Although the number of motoring offences in 2006 was the lowest number dealt with since 2002 , the number receiving penalty charge notices was at the highest level in the last decade; from 3.5 million in 1996 to 7.8 million in 2006 (Figure 9.17).

This increase reflects the change in the treatment of summary motor offences, such as parking, from using criminal penalties 


\section{Figure 9.17}

\section{Motor vehicle offences: by action taken}

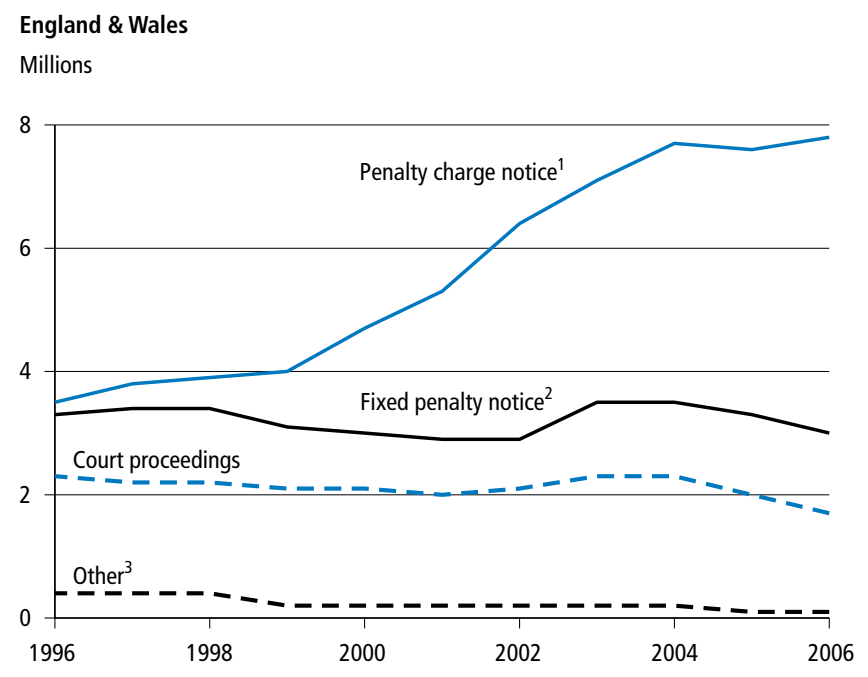

1 Civil notices issued by a council for apparent contraventions to the council's Traffic Regulation Order (bylaw regulations).

2 Notices issued by police officers and police traffic wardens to motorists who commit parking and bus-lane offences governed by criminal law.

3 Includes written warnings and vehicle defect rectification scheme (VDRS) notices.

Source: Ministry of Justice

pursued through the courts to a civil system in which offences are dealt with by the use of fines. This change was reflected in a decrease in the number of offences dealt with using court proceedings, to reach 1.7 million in 2006 and a further fall to 1.4 million in 2007 the lowest number dealt with in this way since the time series began in 1996. In 2007, court proceedings were most often taken for offences within the 'licence, insurance and record-keeping offences' category (including offences of 'driving while disqualified' and 'using motor vehicle uninsured against third party risks') amounting to 724,000, or 51 per cent of offences in 2007, compared with 921,000 in 2006.

Driving while using a hand-held mobile phone became an offence on 1 December 2003 and in 2006 there were 168,500 offences of 'use of hand-held mobile phone while driving' dealt with by the police and parking attendants. Of these, around 98 per cent were dealt with by fixed penalties with the remainder being dealt with by court proceedings or written warnings. In 2007 there were 14,000 court proceedings for 'use of hand-held mobile phone while driving', up from 2,700 in 2006 , reflecting the large number of police force areas taking action against drivers using hand-held mobile phones while driving.

As well as dealing with offenders by the use of non-criminal proceedings such as fines, there are a number of measures aimed at reducing and preventing crime and reoffending. In
England and Wales these measures include community orders, intended to move low-level offenders away from custodial sentences, which can be used instead of, or alongside, other sentences or orders. In addition there are a number of interventions aimed specifically at anti-social behaviour and, in particular, a range of measures to help parents and agencies such as youth offending teams to deal with anti-social behaviour by young people. The interventions available range from one-off fines (fixed penalty notices and penalty notices for disorder) to non-legal agreements, contracts and warnings (including acceptable behaviour contracts and parenting contracts) to court orders that prohibit the perpetrator from specific anti-social behaviours - anti-social behaviour orders (ASBOs) and parenting orders.

ASBOs were introduced in 1999 and are aimed at protecting the public rather than punishing the perpetrator (see Appendix, Part 9: Anti-social behaviour orders (ASBOs)). However, while an ASBO is a civil order that will not appear on an individual's criminal record, a breach of an ASBO is a criminal offence punishable by a fine or a custodial sentence. In 2006, 2,706 ASBOs were issued in England and Wales. Of these around three-fifths $(1,625)$ were issued to individuals aged 18 and over, and two-fifths $(1,054)$ were issued to ten to 17-year-olds (Figure 9.18). The number of ASBOs issued increased every year between 2001 and 2005, but between 2005 and 2006 there was a 34 per cent decrease. This decrease does not necessarily indicate a reduction in the offending behaviour but rather a change in the types of intervention used.

\section{Figure 9.18}

\section{Number of anti-social behaviour orders (ASBOs) issued: ${ }^{1}$ by age}

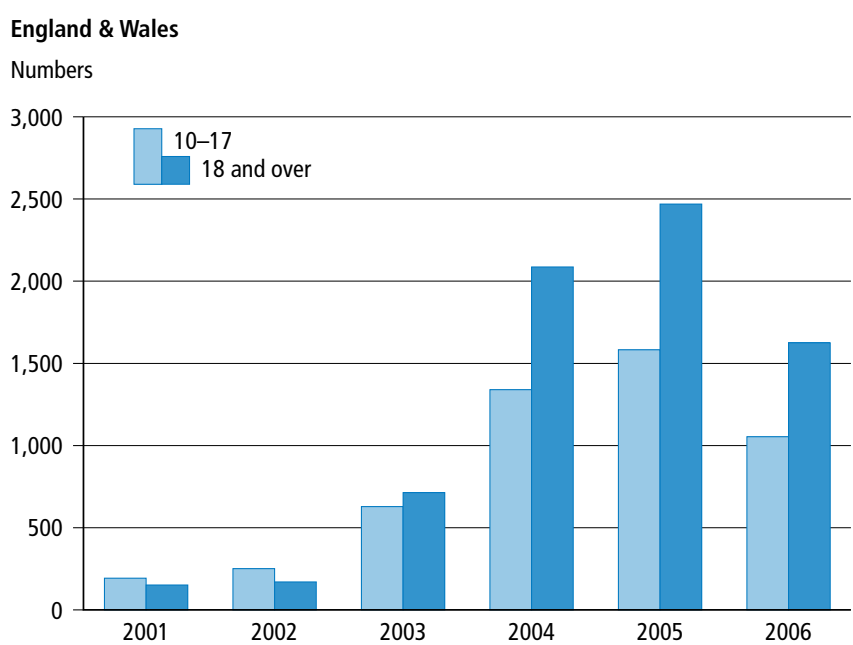

1 Issued at all HM Courts and reported to the Home Office by the Courts Service.

Source: Home Office 
As well as ASBOs, acceptable behaviour contracts ( $A B C s$ ) are written agreements that form a contract between the offender and their local authority, Youth Inclusion Support Panel, landlord or the police. The aim is to engage the individual in recognising the negative effects of their offending behaviour on others and encourage them to stop. Between October 2003 and September 2007 around 30,000 ABCs were issued in England and Wales.

The Anti-Social Behaviour Act 2003 and the Criminal Justice Act 2003 introduced measures aimed at involving parents in reducing anti-social and offending behaviour in the form of parenting contracts (PCs) and parenting orders (POs). A PC is a voluntary written agreement between a youth offending team worker and the parents of a child who is, or is likely to become, involved in criminal or anti-social behaviour. A PO is made in similar circumstances by a court (criminal, family or magistrates') and can be applied where parents are unwilling to co-operate (see Appendix, Part 9: Parenting contracts and parenting orders). Between October 2003 and September 2007 around 9,000 PCs and more than 2,000 POs were issued in England and Wales. As with $A B C s$, a large proportion (around two-fifths) of the total number of PCs and POs were issued between January and September 2007, indicating a rise in the use of these interventions as a form of reducing anti-social behaviour.

Alongside this increase in the range of sentences and orders available for dealing with young offenders (aged ten to 17), a number of measures were also taken to reduce the time taken for them to be dealt with in the criminal justice system. In 1997 the Government set a target to maintain the average time from arrest to sentence specifically for persistent young offenders at or below 71 days (see Appendix, Part 9: Persistent young offenders). This was one-half the average number of days from arrest to sentence in 1996 of 142 days. The target of 71 days was reached in 2002 and has since remained below this level apart from in 2006, when it was 72 days (Figure 9.19).

Between 2006 and 2007 there was a reduction of seven days in the time between arrest and sentencing to 65 days. The first half of 2008 showed a provisional decrease of a further seven days to 58 days.

Overall performance against this target is largely determined by timeliness in the magistrates' courts, where at least nine-tenths of all persistent young offender cases are heard. Although the average number of days between arrest and sentence is much longer for cases at Crown courts, and there was an increase in this time between 2005 and 2006 (from 191 to 214 days), this has little impact on overall timeliness because of the small number of cases involved.

\section{Figure 9.19}

\section{Average number of days from arrest to sentence for persistent young offenders ${ }^{1}$}

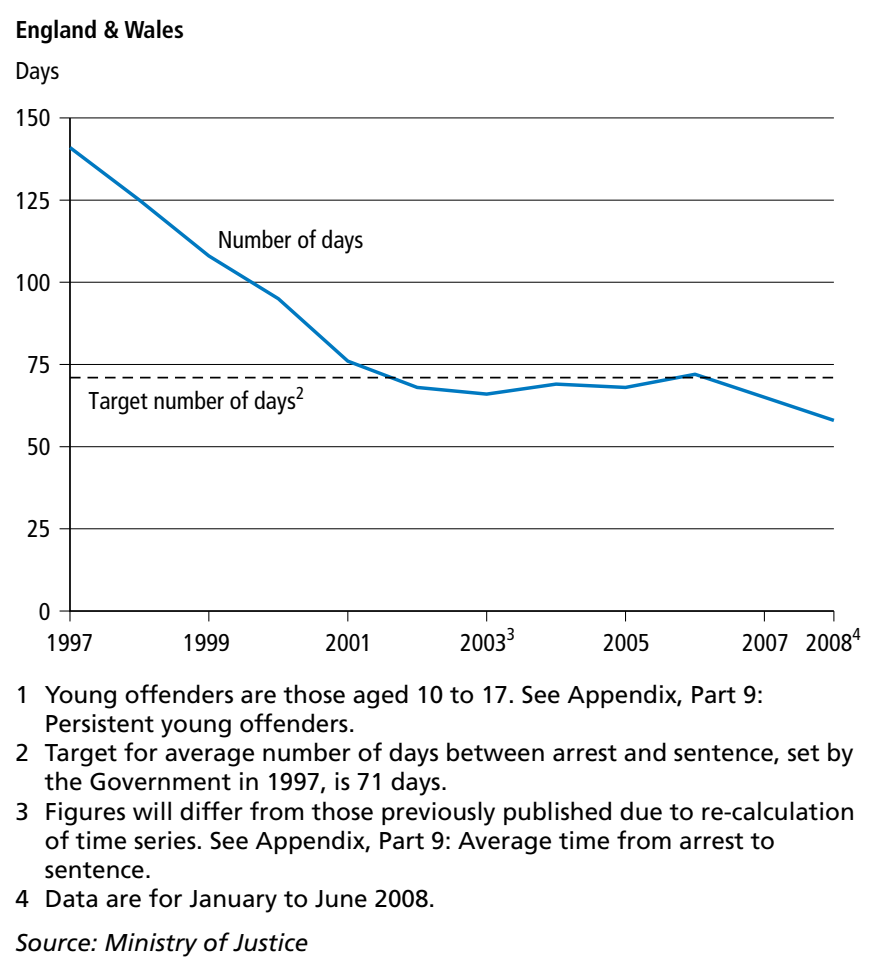

\section{Police and other resources}

There were around 142,000 full-time equivalent police officers in England and Wales in 2008. Around one-quarter (24 per cent) were female and of these 85 per cent were constables, 10 per cent were sergeants and 3 per cent were inspectors. Less than 1 per cent of female police officers were in the senior Association of Chief Police Officers (ACPO) ranks. Overall there has been an increase in the number of police officers in the last ten years, from around 125,000 in 1998, and the proportion of female officers has increased from 16 per cent.

The proportion of police officers who are from an ethnic minority group in England and Wales has also increased over the last decade, from 2 per cent in 1999 to 4 per cent in 2008 (Figure 9.20). In 2008, 4 per cent of constables were from an ethnic minority compared with 2 per cent of chief superintendents. For all other ranks of police officer around 3 per cent were from an ethnic minority.

The proportion of officers who were from an ethnic minority group varied by police force area in England and Wales. In 2008 the London Metropolitan police force area had the highest proportion of ethnic minority officers, at 8 per cent. West Midlands police force had the second highest proportion, at 7 per cent, followed by Leicestershire with 6 per cent. The 


\section{Figure 9.20}

\section{Ethnic ${ }^{1}$ minority officers as a proportion of all police officers ${ }^{2,3}$}

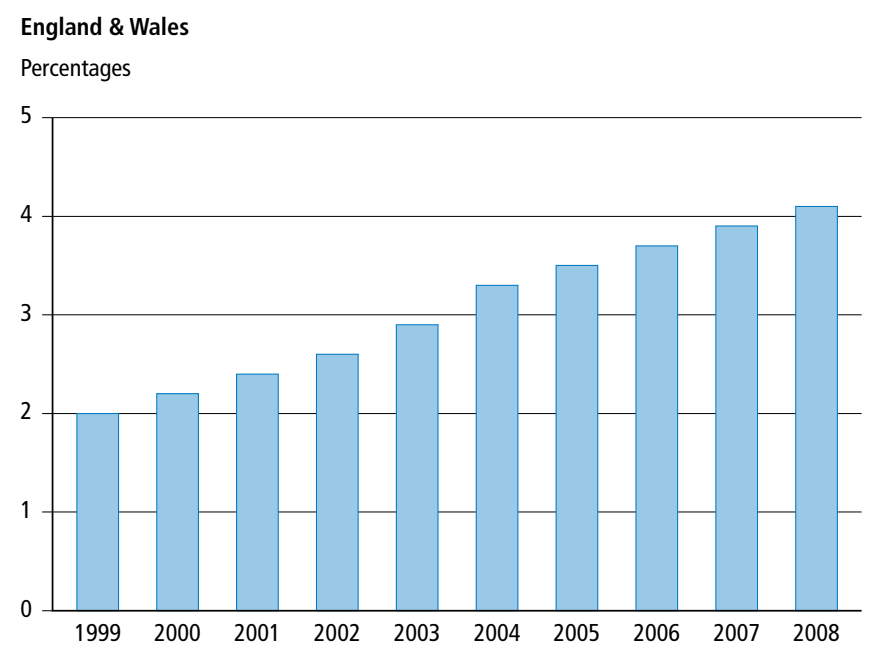

1 See Appendix, Part 1: Classification of ethnic groups.

2 As at 31 March in each year.

3 Proportions for 1999 to 2002 were calculated using the headcount ethnic minority officer strength as a proportion of all full-time equivalent officer strength. The proportions from 2003 were calculated using full-time equivalent ethnic minority strength as a proportion of all full-time equivalent officer strength.

Source: Home Office

police force area with the lowest proportion of ethnic minority officers was North Wales, at less than one-half of 1 per cent. Of the 142,000 police officers in England and Wales in 2008, 2 per cent were Asian or Asian British and 1 per cent each were Black or Black British, or Mixed. In Northern Ireland the proportion of police officers who are from an ethnic minority group has increased every year since 2004, from 0.24 per cent to 0.4 per cent in 2008.

According to the 2007/08 British Crime Survey, almost two-thirds (65 per cent) of people in England and Wales had overall confidence in the police in their local area (Table 9.21), a 1 percentage point increase since 2006/07. More than four-fifths (83 per cent) agreed that the local police would treat them with respect if they had contact with them and almost two-thirds (64 per cent) agreed that their local police would treat everyone fairly regardless of who they are, and that they understand the issues affecting their community (62 per cent). People had the least confidence in relying on their local police to deal with minor crimes (43 per cent).

In Northern Ireland three-fifths (60 per cent) of people had overall confidence in the local police in $2007 / 08$. Four-fifths (81 per cent) agreed that the police would treat them with respect if they had contact with them, around the same proportion as those in England and Wales. The proportions of people agreeing that the police treat everyone fairly regardless

\section{Table 9.21}

\section{Perceptions ${ }^{1}$ of the local police, 2007/08}

England \& Wales

Percentages

Would treat you with respect if you had contact with them

Treat everyone fairly regardless of who they are

Understand the issues that affect this community

62

Are dealing with things that matter to people in the community

Can be relied upon to be there when you need them

Can be relied on to deal with minor crimes

Overall confidence in the local police ${ }^{2}$

65

1 Proportion of respondents who strongly agreed/tended to agree with the statement.

2 Based on question 'Taking everything into account I have confidence in the police in this area'.

Source: British Crime Survey, Home Office

of who they are and that they can be relied on to deal with minor crimes were the same as those for England and Wales (64 per cent and 43 per cent respectively).

The 2007/08 BCS showed that the level of confidence that people in England and Wales had in the criminal justice system (CJS) as a whole had increased compared with 2006/07 in five of the seven areas covered. In particular, the proportion of people who were fairly or very confident that the CJS was effective in bringing people who commit crimes to justice increased by 3 percentage points since 2006/07 to 44 per cent. This is the same increase as the proportion who were either very or fairly confident that the CJS meets the needs of victims of crime (from 33 per cent to 36 per cent between 2006/07 and 2007/08). These increases follow a general decrease in confidence between 2005/06 and 2006/07.

The CJS is one of the major public services in England and Wales. It comprises the Police Service, the Crown Prosecution Service, HM Courts Service, the National Offender Management Service (covering prisons and probation) and the Youth Justice Board. HM Courts Service is responsible for managing the magistrates' courts, the Crown courts, county courts, the High Court and Court of Appeal in England and Wales (see Appendix, Part 9: Courts system in England and Wales).

The judiciary, that is the judges, magistrates and other adjudicators as well as support personnel who keep the courts system running smoothly, account for a large proportion of the courts system resources. In 2008 there were more than 3,800 members of the judiciary serving in England and Wales, of which the largest group (34 per cent) were recorders 
Table 9.22

Composition of the judiciary: ${ }^{1}$ by sex and ethnic group, ${ }^{2} 2008^{3}$

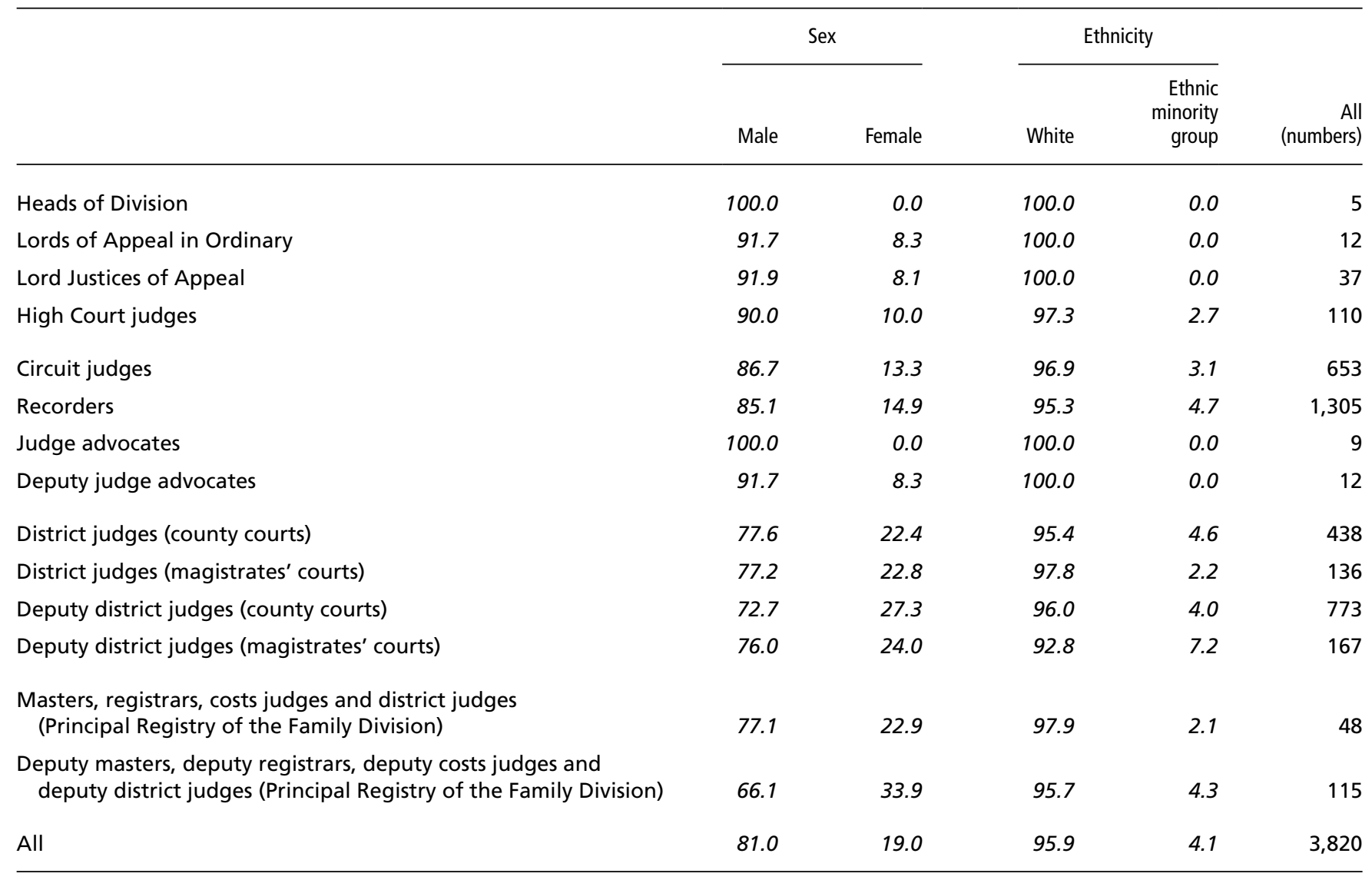

1 See Appendix, Part 9: Judiciary of England and Wales.

2 See Appendix, Part 1: Classification of ethnic groups.

3 As at 1 April 2008.

Source: Judicial Database, Judiciary of England and Wales

(barristers or solicitors who are appointed part-time judges). A further one-quarter (25 per cent) of the judiciary were deputy district judges, 17 per cent were circuit judges and 15 per cent were district judges. Four-fifths (81 per cent) of the total judiciary were men (Table 9.22). Of the women in the judiciary, 35 per cent were deputy district judges and 27 per cent were recorders. The most common position to be held by men was recorder (36 per cent) (see Appendix, Part 9: Judiciary of England and Wales for further information on the separate roles in the judicial system). In 2008, 4 per cent of the judiciary in England and Wales were from an ethnic minority group;

7 per cent of deputy district judges (magistrates' courts), 5 per cent of recorders and district judges (county courts), and smaller proportions, or none, among more senior positions. 